$$
\text { D } 635
$$

. W45

Copy 1 



\section{MESSAGE SENT BY THE PRESIDENT TO THE FARMERS' CONFERENCE AT URBANA, ILL., JANUARY 31, 1918.}

I am very sorry indeed that I can not be present in person at the Urbana conference. I should like to enjoy the benefit of the inspiration and exchange of counsel which I know I should obtain, but in the circumstances it has seemed impossible for me to be present, and therefore I can only send you a very earnest message expressing my interest and the thoughts which such a conference must bring prominently into every mind.

I need not tell you, for I am sure you realize as keenly as I do, that we are as a Nation in the presence of a great task which demands supreme sacrifice and endeavor of every one of us. We can give everything that is needed with the greater willingness, and even satisfaction, because the object of the war in which we are engaged is the greatest that free men have ever undertaken. It is to prevent the life of the world from being determined and the fortunes of men everywhere affected by small groups of military masters, who seek their own interest and the selfish dominion throughout the world of the Governments they unhappily for the moment control. You will not need to be convinced that it was necessary for us as a free people to take part in this war. It had raised its evil hand against us. The rulers of Germany had sought to exercise their power in such a way as to shut off our economic life so far as our intercourse with Europe was concerned, and to confine our people within the Western Hemisphere while they accomplished purposes which would have permanently impaired and impeded every process of our national life and have put the fortunes of America at the mercy of the Imperial Government of Germany.

\section{$8-26561$ reALity, Not Merely a threat.}

This was no threat. It had become a reality. Their hand of violence had been laid upon our own people and our own property in flagrant violation not only of justice but of the well-recognized and long-standing covenants of international law and treaty. We are fighting, therefore, as truly for the liberty and self-government of the United States as if the war of our own Revolution had to be fought over again; and every man in every business in the United States must know by this time that his whole future fortune lies in the balance. Our national life and our whole economic development will pass under the sinister influences of foreign control if we do not win. We must win, therefore, and we shall win. I need not ask you to pledge your lives and fortunes with those of the rest of the Nation to the accomplishment of that great end. 
You will realize, as I think statesmen on both sides of the water realize, that the culminating crisis of the struggle has come and that the achievements of this year on the one side or the other must determine the issue. It has turned out that the forces that fight for freedom, the freedom of men all over the world as well as our own, depend upon us in an extraordinary and unexpected degree for sustenance, for the supply of the materials by which men are to live and to fight, and it will be our glory when the war is over that we have supplied those materials and supplied them zbundantly, and it will be all the more glory because in supplying them we have made our supreme effort and sacrifice.

GREAT AGENCIES AT WORK.

In the ficld of agriculture we have agencies and instrumentalities, fortunately, such as no other government in the world can show. The Department of Agriculture is undoubtedly the greatest practical and scientific agricultural organization in the world. Its total annual budget of $\$ 46,000,000$ has been increased during the last four years more than 72 per cent. It has a staff of 18,000 , including a large number of highly trained experts, and alongside of it stands the unique land-grant colleges, which are without example elsewhere, and the 69 State and Federal experiment stations. These colleges and experiment stations have a total endowment of plant and equipment of $\$ 172,000,000$ and an income of more than $\$ 35,000,000$, with 10,271 teachers, a resident student body of 125,000 , and a vast additional number receiving instruction at their homes. County agents, joint officers of the Department of Agriculture and of the colleges, are everywhere cooperating with the farmers and assisting them. The number of extension workers under the Smith-Lever Act and under the recent emergency legislation has grown to 5,500 men and women working regularly in the various communities and taking to the farmer the latest scientific and practical information.

Alongside these great public agencies stand the very effective voluntary organizations among the farmers themselves which are more and more learning the best methods of cooperation and the best methods of putting to practical use the assistance derived from governmental sources. The banking legislation of the last two or three years has given the farmers access to the great lendable capital of the country, and it has become the duty both of the men in charge of the Federal Reserve Banking System and of the Farm Loan Banking System to see to it that the farmers obtain the credit, both short term and long term, to which they are not only entitled but which it is imperatively necessary should be extended to them if the present tasks of the country are to be adequately performed. Both by direct purchase of nitrates and by the establishment of plants to produce nitrates the Government is doing its utmost to assist in the problem of fertilization. The Department of Agriculture and other agencies are actively assisting the farmers to locate, safeguard, and secure at cost an adequate supply of sound seed. The department has $\$ 2,500,-$ 000 available for this purpose now and has asked the Congress for $\$ 6,000,000$ more.

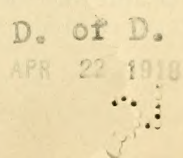


FARM LAISOR AND THE DRAFT.

The labor problem is one of great dificulty, and some of the best agencies of the Nation are addressing themselves to the task of solving it, so far as it is possible to solve it. Farmers have not been exempted from the draft. I know that they would not wish to be. I take it for granted they would not wish to be put in a class by themselves in this respect. But the attention of the War Department has been very seriously centered upon the task of interfering with the labor of the farms as little as possible, and under the new draft regulations I believe that the farmers of the country will find that their supply of labor is very much less seriously drawn upon than it was under the first and initial draft, made before we had our present full experience in these perplexing matters. The supply of labor in all industries is a matter we must look to and are looking to with diligent care.

RESPONSE OF THE FARMERS.

And let me say that the stimulation of the agencies I have enumerated has been responded to by the farmers in splendid fashion. I dare say that you are aware that the farmers of this country are as efficient as any other farmers in the world. They do not produce more per acre than the farmers in Europe. It is not necessary that they should do so. It would perhaps be bad economy for them to attempt it. But they do produce by two to three or four times more per man, per unit of labor and capital, than the farmers of any European country. They are more alert and use more labor-saving devices than any other farmers in the world. And their response to the demands of the present emergency has been in every way remarkable. Last spring their planting exceeded by $12,000,000$ acres the largest planting of any previous year, and the yields from the crops were record-breaking yields. In the fall of 1917 a wheat acreage of $42,170,000$ was planted, which was $1,000,000$ larger than for any preceding year, 3,000,000 greater than the next largest, and $7,000,000$ greater than the preceding five-year average.

\section{SHOCLD EXCEED PAST ACHIEVEMENTS.}

But I ought to say to you that it is not only necessary that these achievements should be repeated, but that they should be exceeded. I know what this advice involves. It involves not only labor but sacrifice, the painstaking application of every bit of scientific knowledge and every tested practice that is available. It means the utmost economy, even to the point where the pinch comes. It means the kind of concentration and self-sacrifice which is involved in the field of battle itself, where the object always looms greater than the individual. And yet the Government will help and help in every way that is possible. The impression which prevails in some quarters that while the Government has sought to fix the prices of foodstuffs it has not sought to fix other prices which determine the expenses of the farmer is a mistaken one. As a matter of fact, the Government has actively and successfully regulated the prices of many fundamental materials underlying all the industries of the country, and 
has regulated them, not only for the purchases of the Government, but also for the purchases of the general public, and I have every reason to believe that the Congress will extend the powers of the Government in this important and even essential matter, so that the tendency to profiteering, which is showing itself in too many quarters, may be effectively checked. In fixing the prices of foodstuffs the Government has sincerely tried to keep the interests of the farmer as much in mind as the interests of the communities which are to be served, but it is serving mankind as well as the farmer, and everything in these times of war takes on the rigid aspect of duty.

\section{AMERICA'S GREATEST OPPORTUNITY.}

I will not appeal to you to continue and renew and increase your efforts. I do not believe that it is necessary to do so. I believe that you will do it without any word or appeal from me, because you understand as well as I do the needs and opportunities of this great hour when the fortunes of mankind everywhere seem about to be determined and when America has the greatest opportunity she has ever had to make good her own freedom and in making it good to lend a helping hand to men struggling for their freedom everywhere. You remember that it was farmers from whom came the first shots at Lexington, that set aflame the revolution that made America free. I hope and believe that the farmers of America will willingly and conspicuously stand by to win this war also.

GLAD WE ARE AMERICANS.

The toil, the intelligence, the energy, the foresight, the self-sacrifice, and devotion of the farmers of America will, I believe, bring to a triumphant conclusion this great last war for the emancipation of men from the control of arbitrary government and the selfishness of class legislation and control, and then, when the end has come, we may look each other in the face and be glad that we are Americans and have had the privilege to play such a part. 

LIBRARY OF CONGRESS

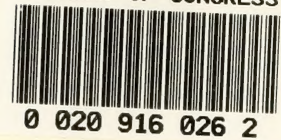

